\title{
Nurul Haramain Narmada Lombok: Alih Kode dan Campur Kode Intern- Ekstern Dalam Peristiwa Tutur Para Santri
}

\author{
Farida Jaeka \\ FKIP Universitas Qamarul Huda Badaruddin \\ faridajaeka99@gmail.com
}

\begin{abstract}
Abstrak
Tulisan ini bermaksud untuk mendeskripsikan berbagai alih kode dan campur kode intern-ekstern yang terdapat pada Pondok Pesantren (PP) Nurul Haramain Narmada Lombok dalam peristiwa tutur yang dilakukan santri dalam beberapa variasi Bahasa, yaitu Bahasa Arab, Indonesia, Inggris, Sasak, dan Samawa. Penelitian kualitatif ini dilakukan dengan metode observasi sebagai langkah awal, dilanjutkan dengan wawancara, serta studi pustaka. Metode observasi dilaksanakan di Pondok Pesantren Nurul Haramain saat peristiwa tutur berlangsung di dalam maupun di luar kelas. Sementara itu, wawancara dilakukan dengan guru terkait tujuan penerapan penggunaan beberapa bahasa dalam berkomunikasi di pondok (sekolah); serta metode studi pustaka digunakan untuk mengumpulkan beberapa data sekunder lainnya. Dari berbagai metode yang dijalankan, didapatkan hasil bahwa terdapat dua jenis alih kode internekstern yang terdiri dari a) alih kode intern-ekstern 3 bahasa (Indonesia-Inggris-Sasak), b) alih kode intern-ekstern 5 bahasa (Indonesia-Inggris-Arab-Sasak-Samawa), juga ditemukan satu peristiwa campur kode, yakni campur kode Ekstern Bahasa Indonesia-Arab.
\end{abstract}

Kata Kunci: Alih Kode Ekstern-Intern, Campur Kode, Nurul Haramain, Santri

\section{PENDAHULUAN}

Sebagai makhluk sosial, manusia membutuhkan bahasa dalam proses komunikasinya. Menurut Joko Nurkamto (dalam Abdurrahman, 2008: 19), komunikasi disebut sebagai suatu proses yang terjadi secara berkelanjutan secara verbal dan non-verbal dengan tujuan mendapatkan pesan yang disampaikan oleh pihak yang berkomunikasi. Nurudin (2016:27) menuliskan bahwa komunikasi manusia merupakan syarat utama adanya sebuah komunikasi. Ia juga menyebutkan bahwa terdapat tiga unsur pokok yang biasanya terdapat di dalam komunikasi yaitu usaha, penyampaian pesan, dan antarmanusia. Bahasa yang digunakan dalam proses komunikasi di tengah suatu masyarakat tersebut dipayungi oleh aturan-aturan tertentu yang telah diatur sedemikian rupa oleh para pendahulu di mana masyarakat tersebut berada. Dalam skala yang lebih spesifik, suatu lembaga telah memiliki aturan-aturan tertentu untuk menggunakan bahasa tertentu pula dalam menjalankan proses komunikasi secara internal. Salah satu contohnya ialah suatu lembaga sekolah. Sekolah memiliki aturan tersendiri di dalam mendidik para siswanya terutama di dalam berkomunikasi di sekolah. Peraturan semacam ini tidak selamanya selaras dengan sekolah atau lembaga lain.

Di Lombok, Nusa Tenggara Barat, terdapat suatu lembaga sekolah, yakni Yayasan Pondok Pesantren Nurul Haramain Narmada yang memiliki aturan tersendiri di dalam berkomunikasi, terutama bagi para santri di dalam internal sekolah. Di dalam internal pondok, terdapat peraturan dalam hal penggunaan bahasa. Artinya, terdapat ragam bahasa yang diterapkan dalam proses komunikasi antar santri-tidak hanya menggunakan Bahasa Indonesia saja. Ragam Bahasa yang utama ialah Bahasa asing, yakni Bahasa Inggris dan Arab. Hal tersebut dilakukan sesuai dengan tujuan pondok pesantren secara umum, yakni menjadikan para santrinya terampil dalam berkomunikasi secara global. Dengan demikian, ragam Bahasa tersebut bukan hanya terjadi di dalam ruang kelas saja, melainkan dipraktekkan dalam peristiwa tutur sehari-hari. Dengan kata lain, pondok terlihat telah memiliki cara tersendiri di dalam mengajarkan Bahasa asing di internal sekolahnya. Padahal, Fachrurrozi dan Mahyudin (2016: 211), sejak pertengahan dekade 1970-an sampai dengan penghujung abad ke-20 M, telah ditawarkan berbagai metode pengajaran Bahasa asing, tetapi hingga hari ini masih saja bergulir pertanyaan tentang metode yang cocok untuk mengajarkan Bahasa Arab dan Inggris baik di sekolah maupun di madrasah. Dengan demikian, penting kiranya agar metode yang diterapkan di pondok Pesantren Nurul Haramain dalam mengajarkan Bahasa asing dijadikan sebagai referensi bagi sekolah/pondok lainnya.

Adanya penerapan Bahasa asing dalam peristiwa tutur sehari-hari mengakibatkan banyak peristiwa alih kode maupun campur kode yang terjadi. Hal tersebut turut pula disebabkan para santri yang memiliki latar belakang bahasa dan budaya yang berbeda. Santri PP Nurul Haramain Narmada Putra berasal dari hampir setiap kabupaten/kota di Nusa Tenggara Barat. Mulai dari yang berada di Pulau Lombok, hingga ke Pulau Sumbawa. Adanya perbedaan latar belakang tersebut menyebabkan Bahasa ibu yang dimiliki oleh 
masing-masing santri pun tidak sama. Ketidaksamaan masing-masing Bahasa ibu ini mau tidak mau harus dileburkan dengan aturan penerapan Bahasa asing dalam setiap peristiwa tutur yang terjadi dalam kesehariannya di dalam pondok. Oleh karena itu, seringkali ditemukan adanya peristiwa alih kode dan campur kode yang terjadi di dalam proses komunikasi para santri. Dengan demikian, tulisan ini bertujuan untuk melihat alih kode dan campur kode yang dilakukan oleh para santri di Pondok Pesantren Nurul Haramain Narmada. Dalam hal ini, peristiwa alih kode dan campur kode yang diamati akan dilihat secara intern, ekstern, dan campuran keduanya (intern-ekstern).

Objek kajian dari penelitian ini ialah santri kelas XI Pondok Pesantren Nurul Haramain Putra Narmada. Penelitian kualitatif ini menggunakan metode observasi, wawancara, dan studi pustaka. Observasi dilakukan di Pondok Pesantren Nurul Haramain Putra, terutama saat proses komunikasi di dalam kelas maupun saat jam istirahat di luar kelas. Sementara itu, wawancara dilakukan dengan guru terkait tujuan penerapan penggunaan beberapa bahasa dalam berkomunikasi di pondok (sekolah). Terakhir, metode studi pustaka digunakan untuk mengumpulkan beberapa data sekunder lainnya dalam rangka melengkapi data yang dibutuhkan. Saat observasi, data dikumpulkan dengan teknik rekam catat. Dilanjutkan dengan teknik wawancara untuk mengumpulkan data sekunder lainnya, serta studi pustaka digunakan dalam menganalisis sampel data yang dikumpulkan. Observasi dan wawancara dilakukan pada April 2021 di PP Nurul Haramain Putra Narmada. Sementara itu, kegiatan studi pustaka dilakukan pada awal penelitian berlangsung hingga pertengahan April 2021.

\section{LANDASAN TEORI}

Eka Bintara dan kawan-kawan pernah melakkan penelitian terkait alih kode dan campur kode pada tahun 2017. Penelitian tersebut "Alih Kode dan Campur Kode dalam Pembelajaran Di Sekolah Menengah Pertama Kabupaten Gunung Kidul”. Penelitian yang dilakukan tersebut menjelaskan tentang bentuk, fungsi, dampak, dan relevansinya dengan proses belajar mengajar di kelas, yakni sebagai bahan ajar untuk kelas VII di SMPN 2 Gedangsari. Hasil penelitian yang dilakukan Eka Bintara dkk tersebut dimanfaatkan sebagai salah satu alternatif materi ajar diskusi pada sekolah tersebut.

Berbeda dengan penelitian tersebut, penelitian ini dilakukan di Pondok Pesantren Nurul Haramain Putra Narmada. Tujuan dari penelitian ini bukan hanya terbatas pada pembelajaran di dalam kelas saja, akan tetapi, diteliti juga mengenai peristiwa tutur yang dilakukan santri-yang menjadi objek kajian-saat di luar jam pelajaran. Jika penelitian yang ditulis Eka Bintara dkk (2017) tersebut dimanfaatkan sebagai materi ajar diskusi kelas 8 di SMP, maka hasil dari penelitian yang dilakukan akan dimanfaatkan oleh sekolah lain yang ingin menerapkan metode efektif dalam mempraktekkan Bahasa asing di sekolah.

Selanjutnya, Rohmani dkk juga pernah melakukan penelitian terkait alih kode dan campur kode Rohmani, dkk dengan judul "Analisis Alih Kode dan Campur Kode Pada Novel Negeri 5 Menara Karya Ahmad Fuadi" pada tahun 2013. Penelitian yang dilakukan tersebut bertujuan untuk mendeskripsikan peristiwa alih kode dan campur kode dari segi bentuknya di dalam novel; alih kode dan campur kode dari segi faktor penyebabnya; serta ingin pula melihat peristiwa alih kode dan campur kode dari segi fungsinya di dalam novel Negeri Lima Menara. Selanjutnya, teknik purposif ialah teknik pengumpulan data yang dilakukan oleh para peneliti. Hasil penelitian tersebut menunjukkan bahwa terdapat 4 formasi dari gejala peristiwa alih kode, sementara gejala campur kode terjalin dalam 7 formasi. Selain itu, ditemukan juga faktor timbulkan peristiwa alih kode yang berhubungan dengan pembicara hingga tujuan serta situasi saat pembicaraan berlangsung. Terakhir, dilihat dari segi fungsi, dapat ditemukan bahwa peristiwa alih kode dan campur kode pada novel berfungsi untuk memerintah, bertanya, menegaskan maksud ,menjelaskan, serta untuk berdoa.

Berbeda dengan beberapa penelitian terdahulu, penelitian ini dilakukan secara langsung di lapangan, yakni berbeda dengan penelitian yang ditulis Rohmani, dkk (2013). Objek kajian dari penelitian terdahulu ialah novel, sementara penelitian yang dilakukan berupa siswa pondok pesantren Nurul Haramain Putra Narmada. Selain itu, teknik pengumpulan data yang dilakukan juga berbeda. Sementara penelitian terdahulu menggunakan teknik purposif, penelitian yang dilakukan menggunakan observasi, wawancara, dan studi pustaka. Oleh karena itu, meskipun antara kedua penelitian memiliki kesamaan dalam hal topik peristiwa alih kode dan campur kode, akan tetapi tetap terdapat celah yang membedakan keduanya. Hal ini berarti bahwa, penelitian terkait alih kode dan campur kode memiliki berbagai celah untuk dikaji. 
Menurut Appel tahun 1976, peristiwa alih kode merupakansuatu peristiwa beralihnya pemakaian bahasa disebabkan oleh perubahan situasi yang terjadi. Di sisi lain, pendapat lain diungkapkan oleh Hymes tahun 1875, bahwa peristiwa alih kode tidak saja terjadi antarbahasa, akan tetapi juga ditemukan antar ragam dalam suatu bahasa (dalam Chaer dan Agustina, 2010:107-108). Dengan berlandaskan pada kedua pendapat tersebut, dapat dikatakan bahwa alih kode sebagai suatu istilah yang menjelaskan perubahan pemakaian bahasa baik antar bahasa maupun ragam bahasa dalam suatu peristiwa komunikasi. Peristiwa komunikasi yang mengandung alih kode di dalamnya terjadi karena beberapa hal, antara lain berasal dari berubahnya topik yang dibicarakan; berasal dari penutur; berasal dari pendengar; berubahnya keadaan atau situasi disebabkan oleh hadirnya seseorang di luar pembicara dan pendengar; serta berubahnya situasi saat pembicaraan berlangsung yakni dari situasi formal menjadi informasl atau sebaliknya (dalam Chaer dan Agustina (2010:108).

Selanjutnya, Soewito membedakan adanya beberapa jenis peristiwa alih kode, yakni alih kode ekstern dan intern. Peristiwa alih kode ekstern dapat terjadi antara bahasa sendiri dengan bahasa asing. Sedangkan, alih kode intern dapat terjadi antar bahasa sendiri, misalnya dari Bahasa Sasak ke Bahasa atau sebaliknya (Chaer dan Agustina, 2010:114).

Berbicara mengenai alih kode, maka tidak terlepas dalam membincangkan campur kode. Hal ini berdasarkan pendapat Hill dan Hill tahun 1980 yang menyatakan bahwa tidak ada ruang celah meskipun kecil yang dapat digunakan dalam memberikan perbedaan antara peristiwa alih kode dan campur kode (dalam Chaer dan Agustina, 2010:114). Kesamaan yang terdapat di antara keduanya yaitu dapat digunakannya 2 atau lebih bahasa, serta 2 varian bahasa dari bahasa dalam suatu masyarakat tutur. Meskipun demikian, setiap istilah selalu memiliki perbedaan di dalam prakteknya. Begitupun yang terjadi antara dua istilah yang disebutkan di atas.

Chaer dan Agustina (2010:114) mencoba memberikan perbedaan antara alih kode dan campur kode. Mereka menyebutkan bahwa di dalam peristiwa alih kode terhadap hal-hal antara lain setiap ragam bahasa selalu memiliki fungsi yang otonom; secara sadar dilakukan; serta terjadi dengan sebab-sebab tertentu. Berbeda halnya dengan peristiwa campur kode, yakni adanya suatu kode dasar yang memiliki fungsi secara otonom sendiri serta terdapat pula kode lainnya (yang terdapat dalam peristiwa tutur yang terjadi) dengan wujud hanya serpihan saja, artinya tidak mengandung fungsi otonom yang menandakannya sebagai sebuah kode.

Perbedaan lain yang dapat digunakan dalam memisahkan kedua istilah di atas ialah dilihat dari struktur gramatikanya. Dalam peristiwa alih kode, adanya sutau peralihan dari satu klausa suatu bahasa ke klausa bahasa lain. Sedangkan, jika hanya frase dari suatu bahasa beralih ke frase bahasa lain, maka peristiwa tersebut telah terjadi campur kode. Pengertian ini selaras dengan pemikiran Thelander (1976) dan Fasold (1984) (dalam Chaer dna Agustina, 2010:115). Dengan demikian, alih kode dapat dicirikan dengan adanya perubahan yang terjadi pada tingkat klausa-yang mana klausa dapat dikategorikan kalimat lengkap. Sedangkan jika yang berubah hanya pada tingkat frase, maka yang terjadi adalah campur kode.

\section{HASIL PENELITIAN DAN PEMBAHASAN}

Peristiwa alih kode dan campur kode yang ditemukan dalam penelitian ini melibatkan beberapa bahasa, yaitu bahasa Indonesia, Arab, Inggris, Sasak, dan Samawa. Meskipun bahasa asing merupakan bahasa dominan yang harus diterapkan dalam berkomunikasi sehari-hari, namun hasil penelitian menunjukkan bahwa alih kode dan campur kode terjadi dalam beberapa bahasa yang telah disebutkan di atas. Hasil penelitian terkait peristiwa alih kode dan campur kode santri kelas XI Pondok Pesantren Nurul Haramain Putra Narmada dapat dilihat dalam tabel berikut. 


\begin{tabular}{|c|c|c|c|}
\hline No & & il Penelitian & Keterangan \\
\hline \multirow{2}{*}{1.} & \multirow{2}{*}{ Alih Kode } & $\begin{array}{l}\text { a. Alih Kode Intern-Ekstern } 3 \\
\text { bahasa } \\
\text { Sasak) }\end{array}$ & Data 1 \\
\hline & & $\begin{array}{l}\text { b. Alih Kode Intern-Ekstern } 5 \\
\text { bahasa (Indonesia-Inggris- } \\
\text { Arab-Sasak-Samawa) }\end{array}$ & Data 2 \\
\hline 2. & Campur Kode & $\begin{array}{lll}\text { a. } & \text { Campur Kode } \\
\text { (Indonesia-Arab) } & \text { Ekstern }\end{array}$ & Data 3 \\
\hline
\end{tabular}

Tabel 1. Hasil Penelitian Alih Kode dan Campur Kode

Tabel di atas menggambarkan bahwa terdapat beberapa bahasa yang digunakan dalam peristiwa alih kode dan campur kode. Dalam penelitian ini, peristiwa alih kode yang dianalisis yakn peralihan pemakaian bahasa, dari bahasa Indonesia ke dalam bahasa asing maupun ke dalam bahasa daerah dan sebaliknya. Sebagaimana yang diungkapkan oleh Suwito (dalam Rohmani, dkk, 2013: 9), bahwa peristiwa dapat dikatakan sebagai sebuah peristiwa peralihan kode bahasa yang satu menuju kode bahasa yang lain. Hal ini berarti bahwa jika terdapat seorang penutur yang awalnya menggunakan kode A (misalnya dalam bahasa Indonesia), kemudian berpindah menggunakan kode B (misalnya Bahasa Sasak), maka peristiwa yang terjadi tersebut dapat dikatakan sebagai peristiwa alih kode. Hal ini sebagaimana data yang terdapat di dalam table di atas. Berikut penjelasannya.

\section{Alih Kode Intern-Ekstern 3 bahasa (Indonesia-Inggris-Sasak)}

Peristiwa alih kode dari Bahasa Indonesia ke Bahasa Inggris dan sebaliknya ditemukan saat santri berkomunikasi dengan sesama santri pada situasi santai. Hal ini disebabkan oleh peraturan penggunaan Bahasa Inggris dalam komunikasi sehari-hari di dalam pondok. Akan tetapi, karena peristiwa tutur terjadi saat situasi informal, maka santri melakukan alih kode ke dalam Bahasa Indonesia. Selain itu, Bahasa Sasak sebagai Bahasa ibu kedua santri juga turut mewarnai peralihan Bahasa yang dilakukan. Hal ini sebagaimana data di bawah ini:

\section{DATA $1^{1}$}

S: Ape pelajarant nane? (apa pelajaran kita sekarang?)

I: Bahasa Inggris. (Bahasa Inggris)

S: Ooh...harus ngomong Inggris ne... (ooh... harus berbicara Bahasa Inggris ya)

I: Yes, of course we must (Iya, tentu saja harus)

S: But, I am not good in English (Tetapi, Bahasa Inggris saya kurang baik)

I: Do you like English? (Apakah kamu suka Bahasa Inggris?)

S: Not too, I like Matematika more than English. Side? (Tidak terlalu, saya lebih suka Matematika daripada Bahasa Inggris. Kalau kamu?)

\footnotetext{
${ }^{1}$ Dalam Data 1, terdapat sumber data yakni santri yang berasal dari kelas XI Bahasa Pondok Pesantren Nurul Haramain Putra Narmada. Nama kedua santri hanya dituliskan inisialnya saja, yakkni S dan I. Hal ini terkait kerahasiaan identitas sumber data. Data diambil pada April 2021
} 
I: Of course, I like it, because if I want do something, I must like it first. (Tentu saja saya suka karena jika saya menginginkan sesuatu, saya harus menyukainya terlebih dahulu)

S: Ooh...maybe because that I can eat so much, because I like eating. (Ooh... mungkin karena itu saya sangat banyak makan, karena saya suka makan)

\title{
I: Pantes maraq dodol ruem. (Pantesan seperti dodol rupamu)
}

S: Wah wah, kantin come on! (Sudah...sudah...ayo ke kantin!)

\section{I: Gass! Traktir...! (Ayoo! Traktir!)}

(Data diambil melalui observasi dan rekaman saat jam istirahat pada April 2021)

Dari data peristiwa tutur di atas, dapat dilihat bahwa antara kedua santri melakukan alih kode internekstern secara bersamaan dalam proses komunikasinya. Dari peristiwa komunikasi tersebut, terdapat Bahasa Indonesia, Sasak, dan Inggris.

Dari awal percakapan, santri S menanyakan tentang pelajaran apa yang akan mereka pelajari di jam selanjutnya dengan menggunakan Bahasa Sasak, Bahasa ibu kedua santri, "Ape pelajarant nane?” (apa pelajaran kita sekarang?). Setelah dijawab bahwa pelajaran selanjutnya ialah Bahasa Inggris, selanjutnya, santri S melakukan peralihan Bahasa Sasak ke Bahasa Indonesia dalam jawabannya, "Ooh...harus ngomong Inggris ne..." (ooh...harus berbicara Bahasa Inggris ya). Dari awal percakan tersebut, kedua santri telah melakukan alih kode Bahasa Sasak ke Bahasa Indonesia (alih kode intern). Akan tetapi, percakapan tidak berhenti hingga di sana. Santri I melakukan peralihan Bahasa Indonesia ke Bahasa Inggris, dan Bahasa Inggris ini mendominasi peristiwa tutur mereka. Dengan kata lain, mereka telah melakukan alih kode ekstern. Seperti diketahui sebelumnya, bahwa Bahasa Inggris merupakan salah satu bahasa yang harus digunakan di dalam berkomunikasi sehari-hari di dalam pondok. Akan tetapi, di akhir komunikasi, mereka melakukan alih kode intern-ekstern lagi, yaitu Bahasa Sasak ("pantes maraq ruen dodol ruem"), Inggris ("come on"), dan Bahasa Indonesia ("Traktir!).

Dari penjelasan di atas, dapat dikatakan bahwa kedua santri tetap berkomunikasi menggunakan Bahasa Inggris (Bahasa Pondok) secara dominan, namun tidak juga meninggalkan Bahasa ibu (Bahasa Sasak) dan Bahasa kedua mereka (Bahasa Indonesia). Dengan demikian, kedua santri tersebut telah melakukan alih kode campuran dalam sekali percakapan, yaitu alih kode Bahasa Sasak, Indonesia, dan Inggris.

\section{Alih Kode Intern-Ektern 5 Bahasa (Inggris-Indonesia-Sasak-Samawa-Arab)}

Selain peristiwa alih kode yang dilakukan santri ke dalam tiga bahasa sekaligus seperti data di atas, data lain menunjukkan bahwa santri juga melakukan peristiwa alih kode ke dalam 5 bahasa sekaligus, yakni Bahasa Inggris, Indonesia, Sasak, Arab, dan Samawa. Data diperoleh saat dalam situasi santri sedang mengantri makan siang di dapur umum di pondok. Hal ini sebagaimana data di bawah ini:

\section{DATA $2^{2}$}

\author{
Z: What our dish now? (Apa lauk kita sekarang?) \\ W: Our dish is delicious (Lauk kita enak!) \\ Z: What is that? (Apakah itu?) \\ W: That is chicken (Ayam) \\ Z: Really? (Sungguh?)
}

\footnotetext{
${ }^{2}$ Dalam Data 2, terdapat sumber data yakni santri yang berasal dari kelas XI Bahasa Pondok Pesantren Nurul Haramain Putra Narmada. Nama kedua santri hanya dituliskan inisialnya saja, yakkni W dan Z. Hal ini terkait kerahasiaan identitas sumber data. Data diambil pada April 2021
} 
W: Maybe. (Mungkin.)

Z: Aidah...kelueqne antrian (Aida...banyak sekali antriannya)

W: Just enjoy the flow (Nikmati saja)

Z: I am so lazy, Bro. Apalagi lauknya terong beleq. (Males, Bro. Apalagi lauknya Terong Beleq)

W: Imagine that is chicken (Bayangkan saja itu ayam)

Z: Ndak saya tahu caranya mengkhayal. (Saya tidak bias membayangkan)

W: Be patient! (Sabar)

Z: Oke deh. Awwalan ya (Iya sudah, duluan ya!)

W: Oke Bro. (Oke Bro)

Dari peristiwa tutur di atas, pada percakapan pertama, santri $\mathrm{Z}$ memulainya dengan Bahasa Inggrisbahasa yang harus diterapkan di pondok sesuai aturan yang berlaku. Santri W, yang merupakan lawan bicaranya juga menggunakan bahasa yang sama. Hingga di percakapan keenam, santri Z mengucapkan interjeksi "Aida..!" yang digunakan saat pembicara merasa heran atau terkejut. Interjeksi tersebut biasanya diucapkan oleh orang Sumbawa atau dengan kata lain berasal dari Bahasa Samawa-bahasa penduduk di Pulau Sumbawa. Santri Z menggunakan interjeksi tersebut karena interjeksi “Aida..!" lumrah digunakan oleh seseorang yang bergaul dengan penutur Bahasa Samawa. Mengingat para santri Nurul Haramain Putra Narmada yang berasal dari hampir setiap kota/kabupaten di Nusa Tenggara Barat, maka interjeksi tersebut tidak asing untuk digunakan di dalam percakapan sehari-hari.

Selanjutnya, dalam satu kalimat, "Aidah...kelueqne antrian”, santri Z mencampurkan Bahasa Samawa dan Bahasa Sasak. Akan tetapi, santri W tetap konsisten menggunakan bahasa awal percakapan mereka, yakni Bahasa Inggris. Kemudian, santri Z mencoba lagi untuk melakukan peralihan bahasa ke dalam Bahasa Indonesia, akan tetapi santri $\mathrm{W}$ tetap menggunakan Bahasa Inggris. Terakhir, santri $\mathrm{Z}$ juga mengalihkodekan peritiwa tutur tersebut ke dalam Bahasa Indonesia dan Arab, yakni "Oke deh. Awwalan ya!". Kata "awwalan" tersebut berasal dari Bahasa Arab yang berarti "duluan". Kata tersebut bukan merupakan frasa. Jadi, tetap dapat dikatakan bahwa peristiwa tersebut merupakan alih kode, bukan campur kode. Hal ini sesuai penjelasan Thelander (1976) dan Fasold (1984) (dalam Chaer dna Agustina, 2010:115), yakni di dalam peristiwa tutur terjadi peralihan dari satu klausa suatu bahasa ke klausa bahasa lain, maka peristiwa tersebut dikategorikan sebagai alih kode. Sedangkan, jika hanya frase dari suatu bahasa beralih ke frase bahasa lain, maka peristiwa tersebut telah terjadi campur kode.

Dari peristiwa tutur yang dilakukan santri $\mathrm{Z}$ dan $\mathrm{W}$ di atas, dapat dilihat bahwa santri $\mathrm{Z}$ merupakan penutur yang selalu mencoba melakukan peralihan bahasa satu ke bahasa lain. Santri W tetap konsisten dengan bahasa awal yang digunakannya, yakni Bahasa Inggris. Dengan dilakukannya alih kode oleh santri Z, maka di dalam peristiwa tutur tersebut didapatkan terjadinya alih kode campuran, yaitu alih kode internekstern Bahasa Inggris, Indonesia, Arab, Samawa, dan Sasak.

Meskipun santri $\mathrm{Z}$ selalu mengalihkodekan peristiwa tutur yang mereka lakukan, akan tetapi santri W tetap menggunakan Bahasa Inggris untuk menghormati dan menaati bahasa pondok yang harus dipraktekkan baik dalam situasi formal maupun informal. Hal tersebut, bukan berarti santri W tidak mampu untuk membalas alih kode beberapa bahasa yang dilakukan santri Z. Akan tetapi, seperti yang disebutkan sebelumnya, bahwa santri $\mathrm{W}$ menghormati dan menaati peraturan penggunaan bahasa di pondok.

\section{Campur Kode Ekstern Bahasa Indonesia-Arab}

Selain ditemukan adanya peristiwa alih kode, data penelitian juga menunjukkan adanya peristiwa campur kode. Dalam hal ini, ditemukan campur kode ekstern Bahasa Indonesia-Arab. Data di bawah terjadi saat santri sedang menuju kamar mandi untuk melaksanakan aktivitas pagi hari di pondok. Hal ini sebagaimana data berikut. 


\section{DATA $3^{3}$}

A: $R$, ayo mandi. Ayo, ambil handuknya (R, ayo mandi. Ayo, ambil handuknya)

R: Di Sholahuddin handuk saya (Handuk saya di Sholahuddin)

\section{A: Hammam Madinah dah, deketan. Kamu aja ke hammam Sholahuddin}

(Kamar mandi Madinah lebih dekat. Kamu saja yang ke Kamar mandi Sholahuddin)

R: Iya dah. (Iya dah)

Dari peristiwa tutur di atas, dapat dilihat adanya peristiwa campur kode. Campur kode yang terjadi ialah saat santri A mengatakan bahwa dia lebih memilih untuk ke hammam Madinah dibandingkan hammam Sholahuddin. Perlu diketahui terlebih dahulu, di pondok, terdapat beberapa istilah untuk menyebut lokasi, salah satunya penyebutan nama kamar mandi. Di antara nama-nama kamar mandi yang ada ialah kamar mandi Madinah dan kamar mandi Sholahuddin. Santri A merasa kamar mandi Madinah lebih terjangkau jaraknya, sehingga ia mengucapkan "Hammam Madinah dah, deketan. Kamu aja ke hammam Sholahuddin", yang menunjukkan adanya peristiwa campur kode Bahasa Indonesia ke Bahasa Arab. Kata hammam yang dituturkan oleh santri tersebut ialah contoh peralihan penggunaan frasa "kamar mandi" dari Bahasa Indonesia ke Bahasa Arab. Dengan demikian, dari peristiwa tutur tersebut, telah terjadi campur kode ekstern Bahasa Indonesia ke Bahasa Arab.

\section{SIMPULAN}

Dari uraian di atas, dapat ditemukan 2 peristiwa alih kode dan 1 peristiwa campur kode. Alih kode yang ada dibagi menjadi dua, yakni a) alih kode intern-ekstern 3 bahasa (Indonesia-Inggris-Sasak), dan b) alih kode intern-ekstern 5 bahasa (Indonesia-Inggris-Arab-Sasak-Samawa). Dalam peristiwa alih kode tersebut, peralihan pemakaian bahasa yang dominan terjadi pada peralihan pemakaian Bahasa Inggris-Sasak. Sementara itu, peristiwa campur kode yang ditemukan hanya campur kode ekstern Bahasa Indonesia-Arab. Leksikon (kelas kata) dominan yang ditemukan dalam peristiwa campur kode tersebut ialah terjadi dalam Bahasa Arab, yakni untuk penyebutan nama tempat, yaitu ialah "Hammam Madinah". Dengan demikian, alih kode dan campur kode yang dilakukan oleh santri kelas XI Pondok Pesantren Nurul Haramain Putra Narmada tidak terlepas dari bahasa ibu masing-masing santri, maupun beberapa bahasa pondok yang harus digunakan dalam berkomunikasi sehari-hari di pondok dan harus dikuasai oleh seluruh santri.

\footnotetext{
${ }^{3}$ Dalam Data 3, terdapat sumber data yakni santri yang berasal dari kelas XI Bahasa Pondok Pesantren Nurul Haramain Putra Narmada. Nama kedua santri hanya dituliskan inisialnya saja, yakkni A dan R. Hal ini terkait kerahasiaan identitas sumber data. Data diambil pada April 2021
} 


\section{DAFTAR PUSTAKA}

Abdurrahman. (2008). "Sosiolinguistik: Teori, Peran, dan Fungsinya Terhadap Kajian Bahasa Sastra". Jurnal Lingua, 3, 18-37

Bintara, Fajar Eka, dkk. (2017). “Alih Kode dan Campur Kode dalam Pembelajaran Di Sekolah Menengah Pertama Kabupaten Gunung Kidul”. Jurnal Basastra, 5, 77-87

Chaer, Abdul dan Leonie Agustina. (2010). Sosiolinguistik: Perkenalan Awal. Jakarta: Rineka Cipta Fachrurrozi, Aziz dan Erta Mahyudin. (2016). Pembelajaran Bahasa Asing: Tradisional dan Edisi Revisi. Jakarta: PT RajaGrafindo Persada Nurudin. (2016). Ilmu Komunikasi: Ilmiah dan Populer. Jakarta: Rajawali Pers

Rohmani, dkk. (2013). “Analisis Alih Kode dan Campur Kode pada Novel Negeri 5 Menara Karya Ahmad Fuadi”. Jurnal Basastra, Vol.1 No.2, 1-16 